\title{
Ukuran Penyebaran Data pada Penjualan Smartphone 2019-2020
}

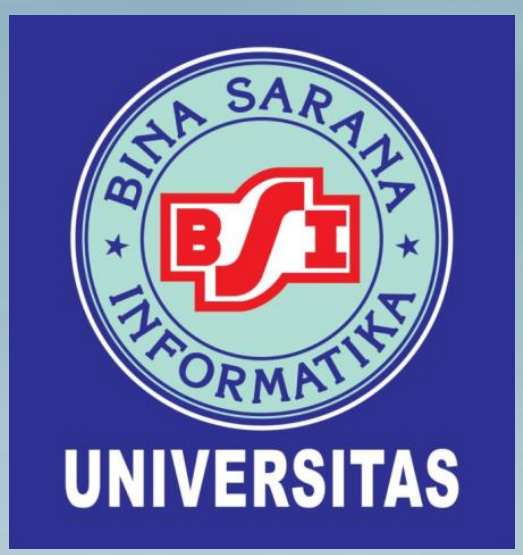

Mata Kuliah Statistika Semester III Jurusan Sistem Informasi Kelompok 2 Kelas 12.3A.27

Disusun Oleh :

1. R. Arie Trihartanto (12192779)

2. Samuel Gibson D (12192096)

3. Theresia Meri Tarigan (12193015) 


\section{Pengertian Ukuran Penyebaran Data}

Ukuran Penyebaran Data adalah ukuran yang menunjukkan seberapa jauh suatu data menyebar dari rata-ratanya.

\section{Pengertian Simpangan rata-rata}

Simpangan rata-rata adalah rata-rata jarak antara nilai-nilai data menuju rataratanya atau rata-rata penyimpangan absolut data dari rata-ratanya

\section{Macam-Macam Penyebaran Data}

- Range untuk Data Tidak Berkelompok

\section{Range $=$ Nilai Terbesar - Nilai Terkecil}

- Range untuk Data Berkelompok

$$
\mathbf{R}=\text { Xmaks }- \text { Xmin }
$$

$\mathrm{R}=$ Range

Xmaks $=$ Nilai tengah kelas Akhir

$\mathrm{Xmin}=$ Nilai tengah kelas Pertama 


\section{Menentukan Ukuran Statistika Dengan}

\section{Excel 2007/2010 Langkah-langkahnya:}

1.Masukkan data pada range (A1:A21)

2.Pilih menu Data pada menu utama

3.Pilih Data Analysis

4.Pilih Deskriptive Statistic pada Data Analysis lalu klik-OK.

\section{- Ketika Box Dialog muncul:}

Pada kotak Input Range, sorot pada range A2:A21

Pada kotak Output Range, ketik C2
Berikan tanda check pada Summary Statistics Kemdian klik-OK.

Pada kotak Output Range, ketik C2
Berikan tanda check pada Summary Statistics Kemdian klik-OK.

- Cara mengolah Data dengan SPSS
1. Klik Analyze ->descriptive statistic $->$ descriptive

- Cara mengolah Data dengan SPSS
1. Klik Analyze ->descriptive statistic -> descriptive
2. Pilih Variabel yang akan dianalisi

1. Klik Analyze ->descriptive statistic
2. Pilih Variabel yang akan dianalisi

3. Klik options

4. Klik ok pada jendela Descriptive

5. Hasil analisis ditampilkan pada jendela output

\section{- Langkah-langkah mengolah data menggunakan Excel \& SPSS :}

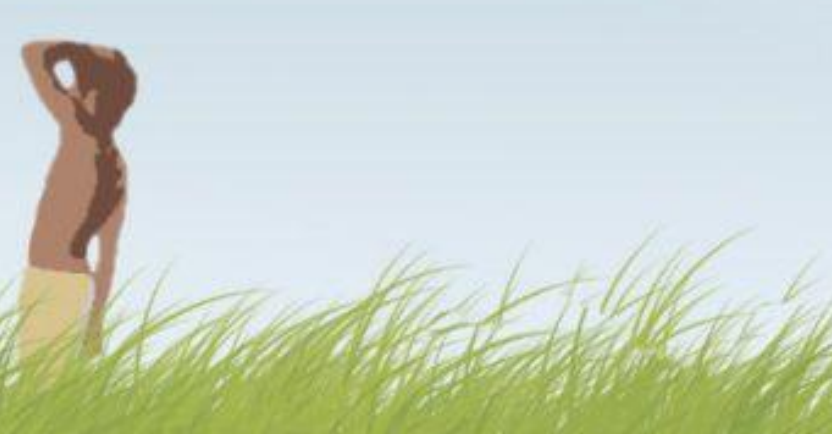
100

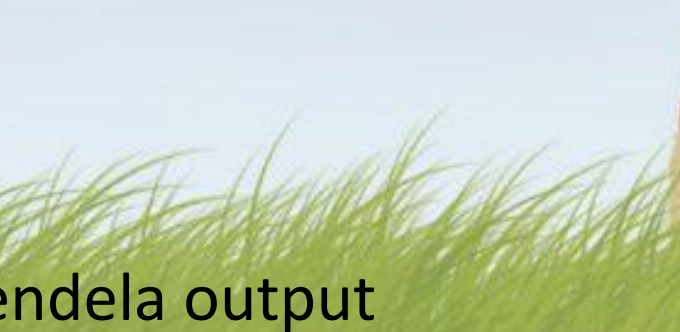




\section{Data Penjualan Smartphone Pada Tahun 2019-2020}

Table 1. Worldwide Smartphone Sales to End Users by Vendor in $1 Q 20$ (Thousands of Units)

Vendor

Samsung

Huawei

Apple

Xiaomi

OPPO

Others

Total
1Q20 1Q20 Market

Units

Share (\%)

55,333

42,499

40,920

27,817

23,949

108,621

299,138
1019 QQ19 Market 1020-1019 Share (\%) Growth (\%)

71,6

$14.2 \quad 58,43$

$13.7 \quad 44,569$

$9.3 \quad 27,424$

$8.0 \quad 29,589$

$36.3 \quad 143,279$

$100.0 \quad 374,917$

$\begin{array}{rr}19.1 & -22.7 \\ 15.6 & -27.3 \\ 11.9 & .8 .2 \\ 7.3 & 1.4 \\ 7.9 & -19.1 \\ 38.2 & -24.2 \\ \mathbf{1 0 0 . 0} & \mathbf{- 2 0 . 2}\end{array}$

Berikut data awal pada Excel :

\begin{tabular}{|l|l|l|l|r|}
\hline \multicolumn{1}{|c|}{ A } & B & \multicolumn{1}{c|}{ C } & \multicolumn{1}{c|}{ D } \\
\hline 1 & & $X$ & \multicolumn{1}{l|}{$Y$} & \\
\hline 2 & Penjualan Smartphone & 2019 & 2020 & Rata-rata \\
\hline 3 & Samsung & 71621 & 55333 & 63477 \\
\hline 4 & Huawei & 58436 & 42499 & 50467 \\
\hline 5 & Apple & 44569 & 40920 & 42744 \\
\hline 6 & Xiaomi & 27424 & 27817 & 27620 \\
\hline 7 & Oppo & 29589 & 23949 & 26769 \\
\hline
\end{tabular}

\section{Tampilan hasil perhitungan :}


Berikut data awal pada SPSS :

\begin{tabular}{|r|r|r|r|}
\hline & \multicolumn{1}{|c|}{ X } & Y & \multicolumn{1}{|l|}{ Z } \\
\hline 1 & 71621 & 55333 & 63477 \\
\hline \hline 2 & 58436 & 42499 & 50467 \\
\hline \hline 3 & 44569 & 40920 & 42744 \\
\hline \hline 5 & 27424 & 27817 & 27620 \\
\hline \hline
\end{tabular}

Tampilan Hasil Perhitungan :

\begin{tabular}{|l|r|r|r|r|c|c|c|c|c|}
\hline \multicolumn{10}{|c|}{ Descriptive Statistics } \\
\hline & \multicolumn{1}{|c|}{ N } & Range & Minimum & Maximum & Sum & \multicolumn{2}{|c|}{ Mean } & Std. Deviation & Variance \\
\cline { 2 - 10 } & Statistic & Statistic & Statistic & Statistic & Statistic & Statistic & Std. Error & Statistic & \multicolumn{1}{c|}{ Statistic } \\
\hline Z & 5 & 36708 & 26769 & 63477 & 211077 & 42215,40 & 6971,517 & 15588,785 & 243010232,3 \\
Valid N (listwise) & 5 & & & & & & & & \\
\hline
\end{tabular}

\section{Kesimpulan}

Ukuran penyebaran Data yang telah dihitung itu Range, deviasi (simpangan baku). Range Data itu menunjukkan selisih antara nilai terbesar dengan nilai terkecil dalam suatu himpunan data. Deviasi suatu jumlah mutlak selisih setiap nilai pengamatan terhadap nilai rata-rata dibagi dengan banyaknya pengamatan. 


\section{Sekian dan Terimakasih}

